University of Nebraska - Lincoln

DigitalCommons@University of Nebraska - Lincoln

U.S. Department of Veterans Affairs Staff

Publications

U.S. Department of Veterans Affairs

$1-17-2004$

\title{
Role of interleukin 6 in myocardial dysfunction of meningococcal septic shock
}

\author{
Nazima Pathan \\ Imperial College of Science, Technology and Medicine, n.pathan@imperial.ac.uk
}

Cheryl A. Hemingway

Imperial College of Science, Technology and Medicine

Ash A. Alizadeh

Stanford University School of Medicine, arasha@Stanford.Edu

Alick C. Stephens

Imperial College of Science, Technology and Medicine

Jennifer C. Boldrick

Stanford University School of Medicine

See next page for additional authors

Follow this and additional works at: https://digitalcommons.unl.edu/veterans

Pathan, Nazima; Hemingway, Cheryl A.; Alizadeh, Ash A.; Stephens, Alick C.; Boldrick, Jennifer C.; Oragui, Emmanuelle E.; McCabe, Colm; Welch, Steven B.; Whitney, Adeline; O'Gara, Peter; Nadel, Simon; Relman, David A.; Harding, Sian E.; and Levin, Michael, "Role of interleukin 6 in myocardial dysfunction of meningococcal septic shock" (2004). U.S. Department of Veterans Affairs Staff Publications. 16.

https://digitalcommons.unl.edu/veterans/16

This Article is brought to you for free and open access by the U.S. Department of Veterans Affairs at DigitalCommons@University of Nebraska - Lincoln. It has been accepted for inclusion in U.S. Department of Veterans Affairs Staff Publications by an authorized administrator of DigitalCommons@University of Nebraska - Lincoln. 


\section{Authors}

Nazima Pathan, Cheryl A. Hemingway, Ash A. Alizadeh, Alick C. Stephens, Jennifer C. Boldrick,

Emmanuelle E. Oragui, Colm McCabe, Steven B. Welch, Adeline Whitney, Peter O'Gara, Simon Nadel, David A. Relman, Sian E. Harding, and Michael Levin 


\title{
Role of interleukin 6 in myocardial dysfunction of meningococcal septic shock
}

\author{
Nazima Pathan, Cheryl A Hemingway, Ash A Alizadeh, Alick C Stephens, Jennifer C Boldrick, Emmanuelle E Oragui, \\ Colm McCabe, Steven B Welch, Adeline Whitney, Peter O'Gara, Simon Nadel, David A Relman, Sian E Harding, Michael Levin
}

\begin{abstract}
Summary
Background Myocardial failure has a central role in the complex pathophysiology of septic shock and contributes to organ failure and death. During the sepsis-induced inflammatory process, specific factors are released that depress myocardial contractile function. We aimed to identify these mediators of myocardial depression in meningococcal septic shock.
\end{abstract}

Methods We combined gene-expression profiling with protein and cellular methods to identify a serum factor causing cardiac dysfunction in meningococcal septic shock. We identified genes that were significantly upregulated in blood after exposure to meningococci. We then selected for further analysis those genes whose protein products had properties of a myocardial depressant factor-specifically a 12-25 kDa heat-stable protein that is released into serum shortly after onset of meningococcal infection.

Findings We identified 174 significantly upregulated genes in meningococcus-infected blood: six encoded proteins that were of the predicted size and had characteristics of a myocardial depressant factor. Of these, interleukin 6 caused significant myocardial depression in vitro. Removal of interleukin 6 from serum samples of patients with meningococcaemia and from supernatants of inflammatory cells stimulated by meningococci in vitro abolished the negative inotropic activity. Furthermore, concentrations in serum of interleukin 6 strongly predicted degree of myocardial dysfunction and severity of disease in children with meningococcal septic shock.

Interpretation Interleukin 6 is a mediator of myocardial depression in meningococcal disease. This cytokine and its downstream mediators could be a target for future treatment strategies.

Lancet 2004; 363: 203-09

Department of Paediatrics, Imperial College of Science, Technology and Medicine, London W2 1PG, UK (N Pathan MRCP, C A Hemingway MRCPCH, A C Stephens PhD, E E Oragui MSc, S B Welch MRCPCH, S Nadel FRCP, Prof M Levin FRCP); Department of Cardiac Medicine, National Heart and Lung Institute, Imperial College of Science, Technology, and Medicine, London (C McCabe BSc, P O'Gara BSc, Prof S E Harding PhD); Department of Biochemistry (A A Alizadeh $\mathrm{PhD}$ ), Department of Microbiology and Immunology (J C Boldrick MD, A Whitney BS, Prof D A Relman MD), and Department of Medicine (Prof D A Relman), Stanford University School of Medicine, Stanford, CA, USA; and Veterans Affairs Palo Alto Health Care System, Palo Alto, CA (Prof D A Relman)

Correspondence to: Dr Nazima Pathan, Department of Paediatrics, Imperial College School of Medicine, St Mary's Hospital, 2nd Floor, Medical School Building, London W2 1PG, UK

(e-mail: n.pathan@imperial.ac.uk)

\section{Introduction}

Septic shock is a major cause of mortality and morbidity in children and adults worldwide. Myocardial dysfunction is a central component in the complex pathophysiology of septic shock, and leads to impaired tissue perfusion, multiorgan failure, and death. Improved treatment of myocardial dysfunction in sepsis has been hampered by poor understanding of the mechanisms involved. Presence of NEGATIVELY INOTROPIC FACTORS released into plasma during sepsis was first documented more than 30 years ago, ${ }^{1}$ and has since been confirmed in many studies. ${ }^{2,3}$ However, the precise nature of a so-called MYOCARDIAL DEPRESSANT FACTOR has not been established.

Many investigators have attempted to characterise myocardial depressant factors in plasma or serum of patients with septic, haemorrhagic, or post-burn shock. ${ }^{2-6}$ Attempts to identify the nature of these factors have produced differing data, including that the agent was of low molecular weight ${ }^{2,4}$ or of a high molecular weight. ${ }^{3}$ Water-soluble ${ }^{2}$ and lipid soluble $\mathrm{e}^{5}$ factors that act acutely ${ }^{2,3}$ or after prolonged incubation ${ }^{6}$ have been reported.

A probable explanation for these conflicting data on the identity of myocardial depressant factors is heterogeneity of patients studied and diversity of their underlying disorders. Many published series of patients with septic shock included adults with a wide range of underlying medical and surgical disorders whose sepsis was caused by many different gram-positive and gram-negative organisms. Furthermore, because of an absence of precise clinical markers of the time of onset of sepsis, patients were studied at different timepoints in their illness.

We postulated that myocardial depressant factors released in gram-negative sepsis could be readily defined by studying one clearly identified disease process affecting previously healthy people without underlying medical or surgical disorders. Meningococcal sepsis is the most frequent infectious cause of death in children in the UK. Myocardial failure is a major feature of meningococcal sepsis. ${ }^{7}$ Severely affected patients have greatly impaired cardiac function, unresponsive to conventional treatment, which can lead to multiorgan hypoxia, ischaemia, and failure.

We have previously reported that serum of children with meningococcal septic shock contains a myocardial depressant protein factor of $12-25 \mathrm{kDa},{ }^{8}$ which is released after exposure of peripheral blood cells to meningococci in vitro, with maximum release happening at $3 \mathrm{~h}^{8}{ }^{8} \mathrm{We}$ therefore reasoned that this myocardial depressant activity is attributable to a newly synthesised protein or proteins, and that the gene or genes encoding this myocardial depressant factor would be upregulated in peripheral blood cells early after exposure to meningococci. We postulated that the protein causing myocardial depression could be identified with HIGH-DENSITY GENE MICROARRAY EXPRESSION PROFILING, to predict candidate genes, based on the known physiochemical properties of the protein. 


\section{GLOSSARY \\ HIGH-DENSITY GENE MICROARRAY EXPRESSION PROFILING A technique whereby the relative abundance or absence of thousands of genes can be determined simultaneously. Fluorescence-labelled RNA transcripts are hybridised onto a glass slide onto which specific cDNA clones are spotted. The absolute fluorescence intensity of the signal is then measured and a ratio of the genes present can be calculated. \\ MYOCARDIAL DEPRESSANT FACTOR \\ Circulating factor or factors that impair cardiac contractility in septic shock. \\ NEGATIVELY INOTROPIC FACTORS \\ Factors causing impaired cardiac contractility. \\ PLEIOTROPIC CYTOKINE \\ A cytokine that affects activity of various cell types.}

We aimed to identify the myocardial depressant factor or factors released from serum in meningococcal disease.

\section{Methods}

\section{Patients}

Between September, 1998, and July, 2002, we obtained blood samples from patients with severe meningococcal septic shock, for whom parental consent had been obtained, on admission to the intensive care unit of St Mary's Hospital, London, UK. We obtained approval of the local research ethics committee of this institution. Mean time of sampling was $5.4 \mathrm{~h}$ after initial presentation to hospital and administration of antibiotics. We confirmed the diagnosis of meningococcal disease clinically and microbiologically by culture, serology, or rapid antigen screen. Severity of disease was defined with the wellvalidated PRISM (paediatric risk of mortality) III score, ${ }^{9}$ on the basis of physiological variables measured in the first $24 \mathrm{~h}$ of admission.

\section{Procedures}

Characterisation of trace biologically active substances in complex solutions such as serum or cell supernatants has traditionally been undertaken by protein purification, which needs large volumes of active solution. The small quantities of serum available from critically-ill children with meningococcal disease made this approach impractical. We therefore combined high-density cDNA microarray technology and conventional immunochemical methods.

We obtained rat ventricular myocytes from adult male Sprague-Dawley rats $(300-400 \mathrm{~g})$. Single-cell suspensions were prepared by collagenase perfusion. We measured Stimulate blood with meningococci

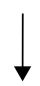

Recover RNA at 2-3 h

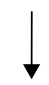

Identify genes upregulated by expression profile on high density cDNA microarrays

Select candidate genes that are secreted, molecular weight $12-25 \mathrm{kDa}$

Test candidates for biological activity

Figure 1: Strategy to identify myocardial depressant factors in meningococcal septic shock myocyte contraction amplitude and speed of contraction and relaxation before, during, and after exposure to the test substance, as previously described. ${ }^{8}$ Myocytes were exposed to each of the candidate proteins individually over a dose range similar to amounts seen in meningococcal disease.

We infected heparinised whole blood from two healthy donors (adult volunteers) with $10^{8}$ live meningococci, serogroup B, type MC58, as previously described. ${ }^{8}$ Blood was incubated at $37^{\circ} \mathrm{C}$ for $0,1,3,6,12$, and $24 \mathrm{~h}$. At every timepoint we removed a sample and harvested the plasma by centrifugation $(1200 \mathrm{~g}, 10 \mathrm{~min})$. We gathered the remaining blood into RNA stabilisation fluid. Uninfected control blood was obtained for every timepoint.

We extracted total RNA with the PreAnalytix RNA extraction kit (Qiagen, Crawley, UK), as described in the kit protocol. Duplicate RNA samples were obtained at every timepoint from each donor, with a resulting four RNA samples for each timepoint. After linear amplification $^{10}$ and reverse transcription to cDNA, we combined the RNA-derived cDNA sample with a reference cDNA (derived from a pool of RNA from a panel of 11 human cell lines, of equal quantity). Every sample was first labelled with two distinct fluorescent nucleotides (Amersham Pharmacia, Chalfont, Bucks, $\mathrm{UK})$ : Cy3-dUTP $(550 \mathrm{~nm})$ for the reference, and Cy5-dUTP $(649 \mathrm{~nm})$ for the sample. The probe was washed, concentrated, and competitively hybridised to custom-printed cDNA microarrays containing 37632 hybridisation elements for about 18000 expressed human genes. ${ }^{11}$

We scanned the slides with laser microscopy (GenePix 4000A, Axon instruments, Union City, CA, USA), with every spot on the array given a relative fluorescence ratio for sample and reference RNA. Areas of the array with blemishes or poor quality spots were flagged and excluded from analysis. We filtered data so that only those spots that were well measured on at least $80 \%$ of the arrays, and showing at least two-fold change from baseline in both donors, were included. The remaining gene expression ratios were log-transformed and centred by subtracting the median observed value on every array. Data were then zero-transformed-ie, baselined-with a custom Microsoft Excel macro (DataProc). ${ }^{12}$ Specifically, the average time zero measurement for each donor was then subtracted from every subsequent timepoint measurement to depict temporal response patterns of expression relative to $t=0$ as the baseline.

Transformed data were hierarchically clustered on the gene axis with the average linkage method by Cluster (version 2.20), ${ }^{13}$ and results were analysed with Treeview software (version 1.60)..$^{13}$ All datasets and image files used in the whole blood stimulation experiment are publicly available in both raw and MIAME-compliant formats ${ }^{14}$ through the Stanford microarray database, ${ }^{15}$ and in the webfigure (http://image.thelancet.com/extras/03art7298 webfigure.pdf). With the Stanford microarray database, ${ }^{15}$ data were selected from the microarrays for unique arrayed cDNA elements that had a fluorescence intensity in either channel of at least $2 \cdot 5$-fold over background intensity for either the Cy3 or Cy5 channel.

We isolated peripheral blood mononuclear cells from donor blood by density gradient centrifugation, and resuspended them in RPMI medium (Sigma Chemical, Poole, UK) with $10 \%$ fetal calf serum, as previously described. $^{8}$ Cells were stimulated with $10^{8}$ colonyforming units per $\mathrm{mL}$ of heat-killed Neisseria meningitidis for $4 \mathrm{~h}$. After incubation, we recovered the supernatant by centrifugation $(1200 \mathrm{~g}, 10 \mathrm{mins})$ and stored it at $-80^{\circ} \mathrm{C}$. 


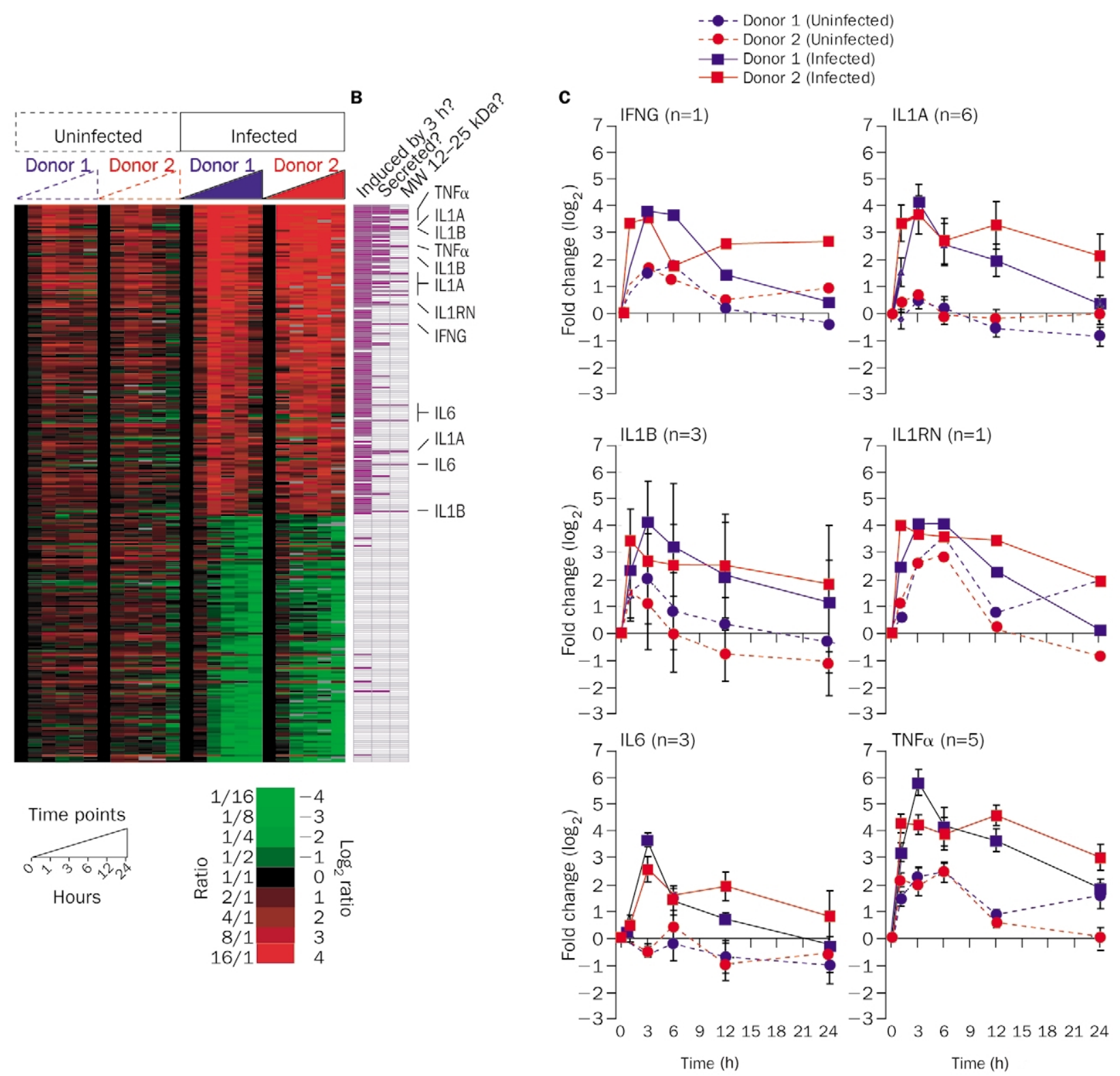

Figure 2: Identification of genes coding for candidate myocardial depressant factors

Gene expression profiles of whole blood incubated with live meningococci for up to $24 \mathrm{~h}$ (infected) and control samples (uninfected). IL=interleukin.

IFNG=interferon $\gamma$. (A) 299 cDNAs (about 174 genes) were identified showing prominent responses to meningococcal infection and concordance in both donors (as described in the webfigure). (B) Purple bars indicate genes that were upregulated at $3 \mathrm{~h}$, were secreted, and had a molecular weight (MW) of 12-25 kDa. (C) Timecourse of expression of genes meeting all three myocardial depressant factor criteria. Depicted datapoints represent the geometric mean of independent $c D N A$ elements as a ratio $\left(\log _{2}\right)$ relative to pretreatment timepoint. Error bars=SD.

Activated sepharose columns (HiTrap, Amersham Biosciences, Bucks, UK) were coupled with $1 \mathrm{mg}$ polyclonal antihuman tumour necrosis factor $\alpha(\mathrm{TNF} \alpha)$ or with polyclonal antihuman interleukin 6 ( R \& D Systems, Oxon, UK). We loaded supernatant of peripheral blood mononuclear cells or meningococcal serum onto the column. The unbound (cytokinedepleted) fraction was eluted with Tyrode's solution $(150.0 \mathrm{mmol} / \mathrm{L} \mathrm{NaCl}, 5 \cdot 4 \mathrm{mmol} / \mathrm{L} \mathrm{KCl}, 1.2 \mathrm{mmol} / \mathrm{L}$ $\mathrm{MgCl}_{2}, 2.0 \mathrm{mmol} / \mathrm{L} \mathrm{CaCl}_{2}, 10 \mathrm{mmol} / \mathrm{L} \mathrm{Glu}$, and 5 $\mathrm{mmol} / \mathrm{L}$ sodium HEPES with $\mathrm{pH}$ adjusted to $7 \cdot 4$, at $37^{\circ} \mathrm{C}$ ). The bound (cytokine-containing) fraction was recovered by eluting the column with glycine- $\mathrm{HCl} \mathrm{pH} 3$ solution and dialysing against water for $2 \mathrm{~h}$ and then against Tyrode's solution overnight with Visking tubing (Visking, Liverpool, UK).

We measured concentrations in serum of interleukin 6 in patients' samples and stimulated peripheral blood mononuclear cells supernatant by ELISA with rabbit polyclonal antihuman cytokines (Boehringer Mannheim, Lewes, UK), as detailed in the kit protocol.

To correlate interleukin 6 concentrations with disease severity, we also included in our study patients from the multicentre trial of $\mathrm{rBPI}_{21}$ in meningococcal sepsis. ${ }^{16}$ Samples were taken before administration of drug or placebo, and access to data was granted by Xoma (Berkeley, CA, USA).

\section{Statistical analysis}

We measured all outcomes on a continuous scale. Differences in contraction amplitude and percentage change in contraction amplitude between pairs of groups were assessed with Mann-Whitney tests, whereas we used the Kruskal-Wallis test to assess the difference in serum concentration of interleukin 6 between different clinical groups. We calculated the relation between serum 


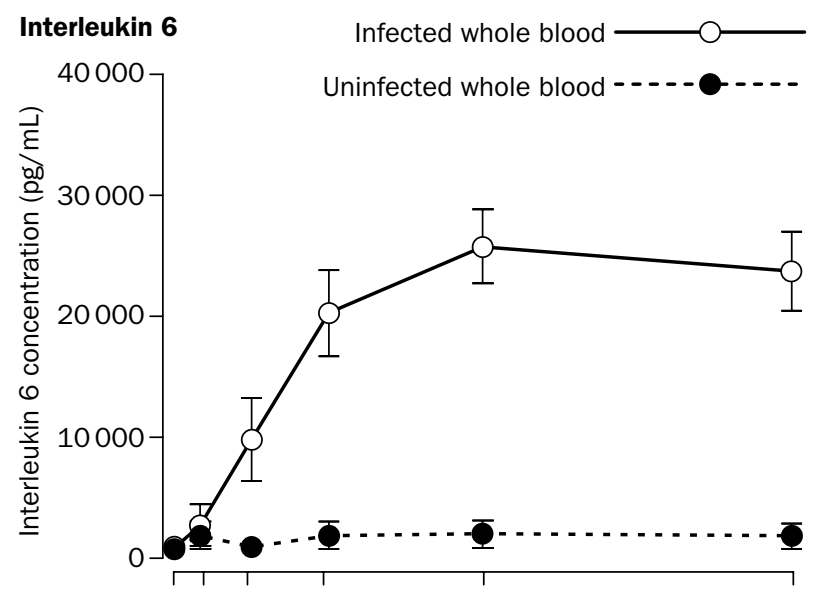

TNF $\alpha$

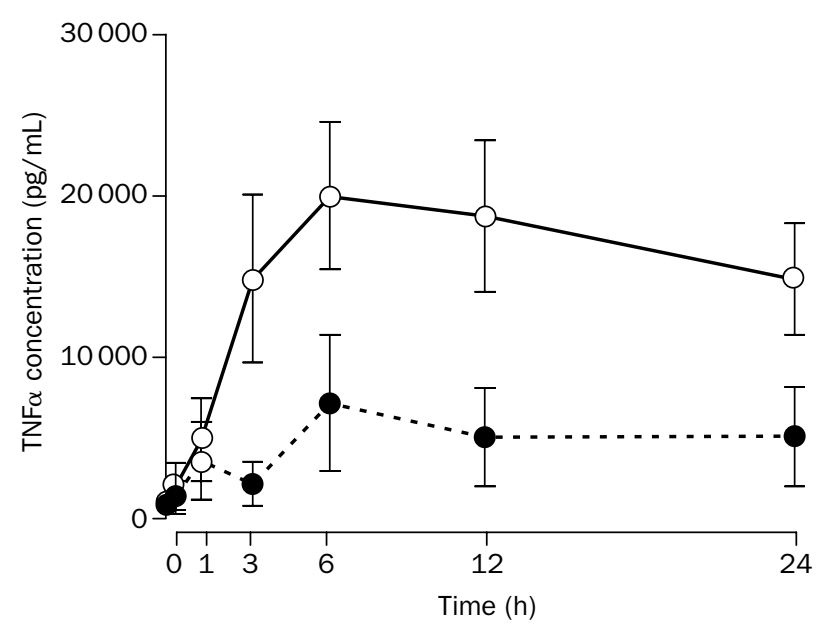

Figure 3: Protein concentrations of TNF $\alpha$ and interleukin 6 during in-vitro infection of whole blood with $\mathbf{N}$ meningitidis Values are mean, error bars show SD. For corresponding mRNA expression, see figure $2 \mathrm{C}$.

concentration and PRISM III score with Pearson correlation.

\section{Role of the funding source}

The sponsors of the study had no role in study design, data collection, data analysis, data interpretation, or writing of the report.

\section{Results}

Our experimental strategy to identify the myocardial depressant factor or factors is summarised in figure 1 .

We first sought to identify candidate genes that were upregulated on exposure of peripheral blood cells to meningococci. We identified a set of about 174 genes with strongly altered expression after exposure to meningococci, which were concordant in two separate donors (figure $2 \mathrm{~A}$; webfigure). Within this set of genes, we found only six that fitted our criteria for myocardial depressant factor candidates.

The six myocardial depressant factor candidates identified were interleukins $1 \alpha, 1 \beta$, and 6 , IL-1RN (interleukin 1 receptor antagonist), interferon $\gamma$, and $\mathrm{TNF} \alpha$ (figure $2 \mathrm{C}$ ). Of these, IL-1RN was excluded from analysis since we observed significant non-specific induction within the uninfected time series of both donors. The remaining five myocardial depressant factor candidates represent major proinflammatory cytokines, and are canonical markers of the sepsis-induced inflammatory process.

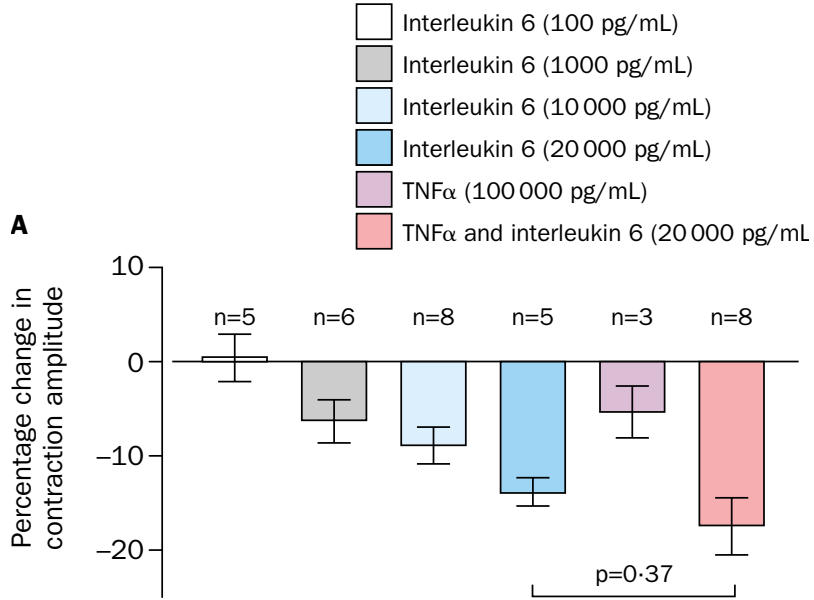

B

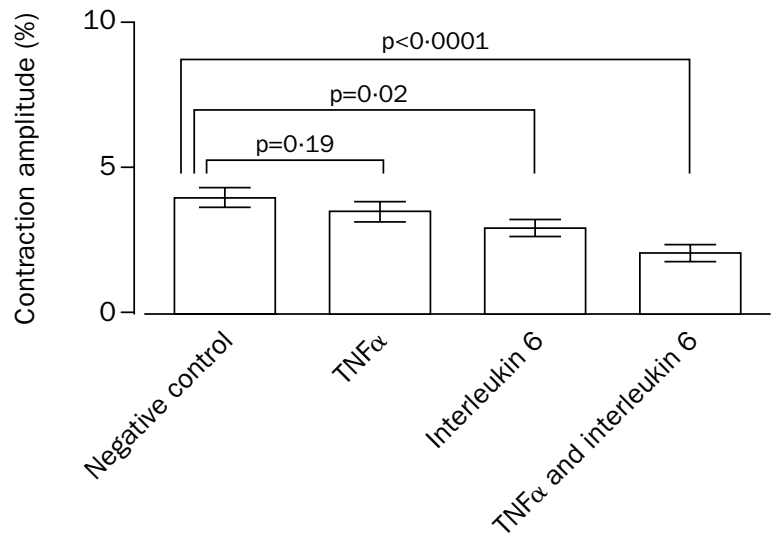

Figure 4: Effect of TNF $\alpha$ and interleukin 6 on myocyte contraction amplitude

(A) Acute changes in contraction of cardiac myocytes following exposure to TNF $\alpha$ or interleukin 6. (B) Effect of TNF $\alpha$ and interleukin 6 on myocyte contraction after $48 \mathrm{~h}$ exposure.

We found close concordance between mRNA expression and concentration of released protein for a confirmatory subset of these genes with specific ELISA for $\mathrm{TNF} \alpha$, and interleukin 6 (figure 3), confirming the validity of the gene expression profiling.

We tested recombinant human candidate proteins for myocardial depressant activity with isolated rat cardiac myocytes. The effect of these proteins was compared with myocardial depressant activity of serum samples from patients with meningococcaemia and of supernatants from inflammatory cells treated with meningococci. Only interleukin 6 induced a dosedependent myocardial depression (figure $4 \mathrm{~A}$ ). $\mathrm{TNF} \alpha$ had no significant effect on myocyte contractility. Addition of $\mathrm{TNF} \alpha$ to interleukin 6 did not increase the myocardial depressant effect. At $20000 \mathrm{pg} / \mathrm{mL}, \mathrm{TNF} \alpha$ caused a mean change in contraction amplitude of $+2 \cdot 8 \%(\mathrm{SD} 5 \cdot 1 ; \mathrm{n}=5)$; at $100000 \mathrm{pg} / \mathrm{mL}$, the reduction was $-5 \cdot 35 \%$ (SD $4 \cdot 7$ ). By contrast, $20000 \mathrm{pg} / \mathrm{mL}$ of interleukin 6 caused a mean change in contraction amplitude of $-13.9 \%$ (SD 3.3 ), whereas a combination of $\mathrm{TNF} \alpha$ and interleukin 6 caused a mean change of $-17 \cdot 6 \%(8 \cdot 2$; figure $4 \mathrm{~A})$.

We noted that purified recombinant interleukin 6 also mimicked the chronic depressant effects of meningococcal serum. Myocytes cultured with interleukin $6(1000 \mathrm{pg} / \mathrm{mL})$ for $48 \mathrm{~h}$ had a mean contraction amplitude of $4.97 \%$ (SD $2 \cdot 9$ ), whereas 


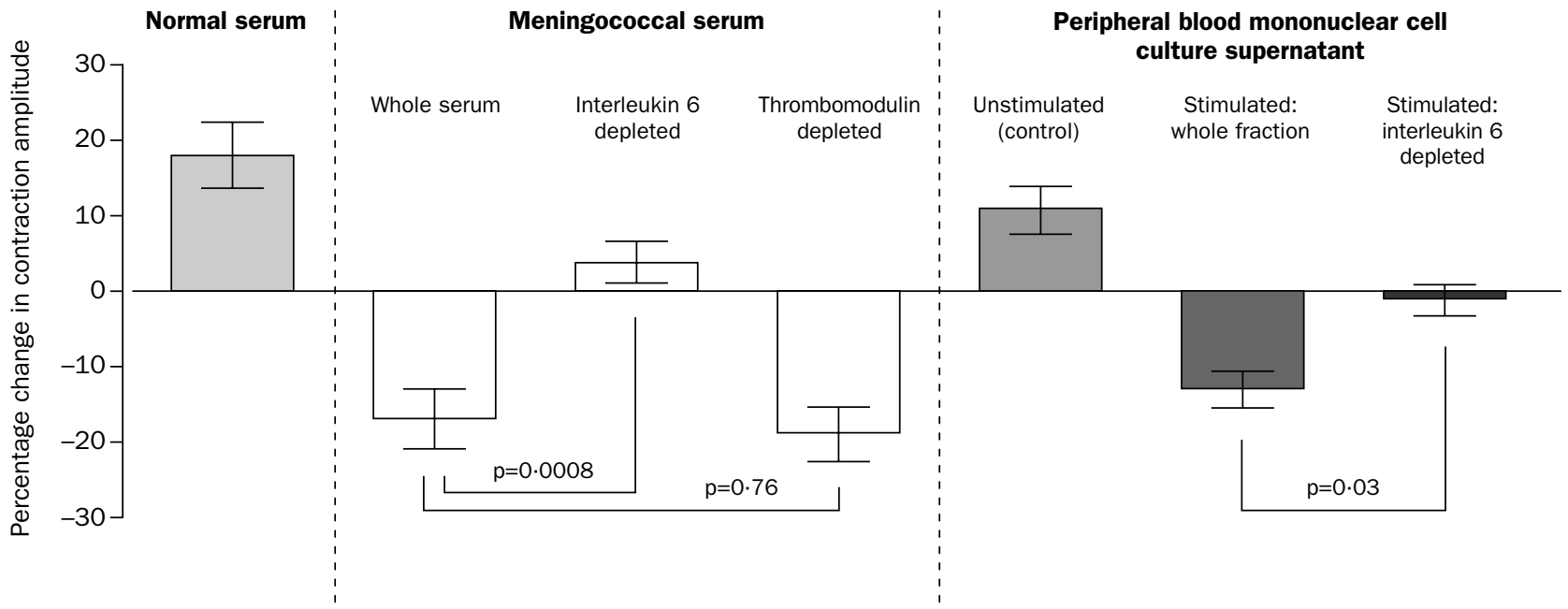

Figure 5: Effects of interleukin 6 removal on myocardial depressant activity of meningococcal serum and meningococcal stimulated peripheral blood mononuclear cell supernatant

that of cells exposed to a combination of $\mathrm{TNF} \alpha$ and interleukin 6 was $3 \cdot 48 \%(2 \cdot 8 ; \mathrm{p}=0 \cdot 03$, unpaired $t$ test $)$. Myocytes cultured in cytokine-free conditions had a mean contraction amplitude of $6 \cdot 77 \%$ (SD $3 \cdot 2 ; n=36$ for each condition). Thus, depressant activity of interleukin 6 was similar in time course, duration, and extent to that of meningococcal serum and meningococcal activated peripheral blood mononuclear cells supernatant (figure $4 \mathrm{~B}$ ). $\mathrm{TNF} \alpha$ enhanced the negative inotropic activity of interleukin 6 after prolonged exposure, but had no significant depressant activity alone or in combination with interleukin 6 on acute exposure.

We compared the ability of serum from ten acutely ill patients with meningococcal disease to induce myocardial depression before and after removal of interleukin 6 or $\mathrm{TNF} \alpha$ by immunoadsorption (figure 5). Mean change in contraction amplitude of ten untreated

\section{A}

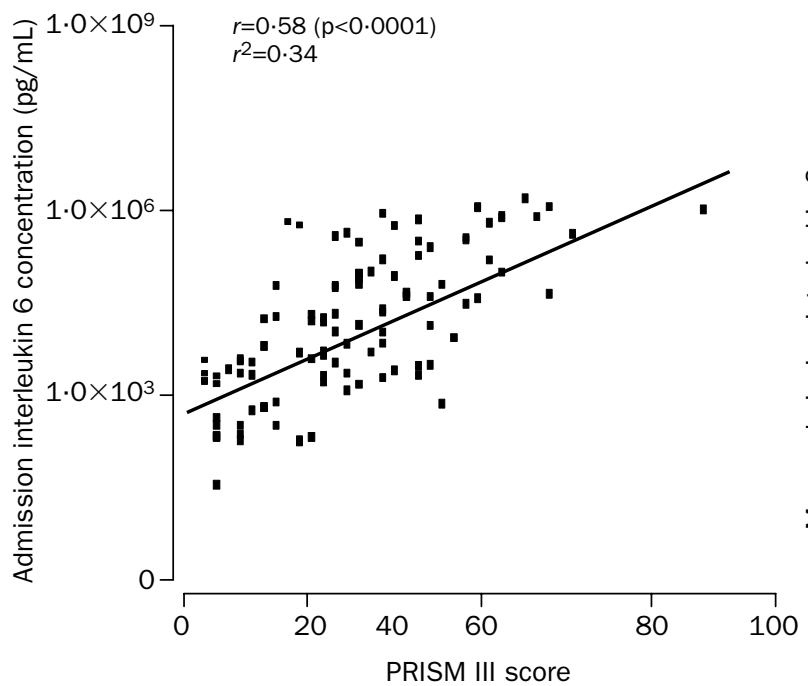

meningococcal serum samples was $-16 \cdot 74 \%$ (SD $4 \cdot 5$ ), whereas in interleukin-6-depleted meningococcal serum, mean change was $+4 \cdot 08 \%$ (SD $3 \cdot 2 ; n=10$ ). Immunoadsorption with an unrelated antibody (antithrombomodulin) had no effect on the myocardial depressant activity of meningococcal serum. Depletion of interleukin 6 by affinity immunoadsorption completely abolished the myocardial depressant activity of meningococcus-stimulated peripheral blood mononuclear cells supernatants (figure 5). After recovery of bound interleukin 6 from the sepharose column, myocardial depressant activity was shown to be present in the fraction adsorbed to the column. Removal of $\mathrm{TNF} \alpha$ did not significantly reduce the negative inotropic activity of meningococcal serum. Mean change in contraction amplitude of myocytes exposed to meningococcal serum before $\mathrm{TNF} \alpha$ removal was $-25 \cdot 5 \%$ (SD $24 \cdot 1 ; \mathrm{n}=7$ ), and that after $\mathrm{TNF} \alpha$ removal

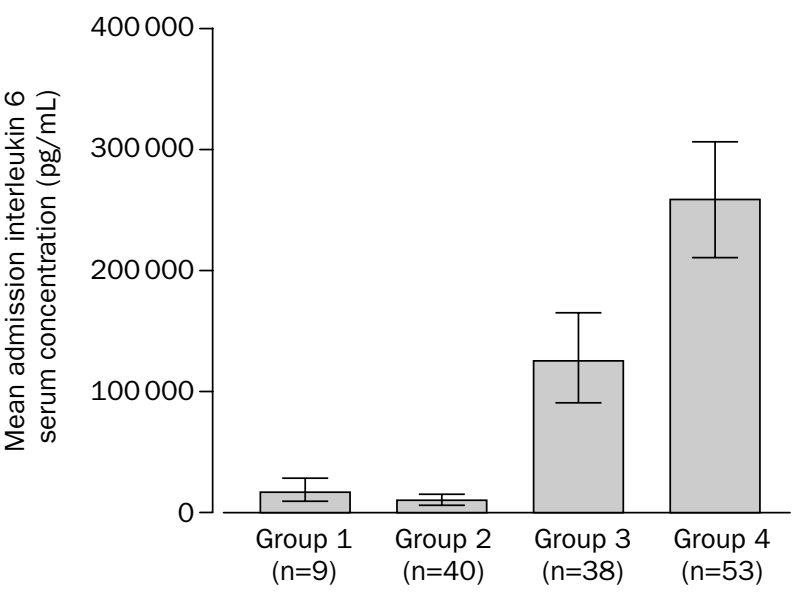

Figure 6: Association between interleukin 6 and clinical disease severity

(A) Correlation of PRISM III score and interleukin 6 serum concentration. (B) Severity of myocardial dysfunction on the basis of need for inotropic support. Values are mean. Error bars=SE. Group 1=no inotropes needed. Group 2=mild to moderate shock; dopamine or dobutamine up to $10 \mu g \mathrm{~kg}^{-1} \mathrm{~min}^{-1}$. Group 3=moderately severe shock; higher doses of dopamine or dobutamine, epinephrine or norepinephrine, or both needed, up to $0.4 \mu g \mathrm{~kg}^{-1} \mathrm{~min}^{-1}$. Group 4=severe shock; epinephrine or norepinephrine doses of $>0.4 \mu \mathrm{g} \mathrm{kg}{ }^{-1} \mathrm{~min}^{-1}$. Admission concentrations of interleukin 6 were significantly increased in patients who had impaired myocardial dysfunction. The difference in amount of interleukin 6 in patients in each of the four groups was significant $(p<0 \cdot 0001$, Kruskall-Wallis test). 
was $-10 \cdot 5 \%(\operatorname{SD~} 9 \cdot 1 ; p=0 \cdot 13 ; n=7)$. Furthermore, the fraction containing $\mathrm{TNF} \alpha$ did not have significant myocardial depressant activity (mean change in contraction amplitude $-6 \cdot 3 \%$ [SD $7 \cdot 3 ; \mathrm{p}=0 \cdot 27 ; \mathrm{n}=4]$ ).

We analysed the association of serum concentration of interleukin 6 with disease severity, as measured by the PRISM III score, in 140 patients admitted with severe meningococcal disease, and found a significant correlation $(r=0.58 ; \mathrm{p}<0.0001$; figure $6 \mathrm{~A})$. Myocardial dysfunction, as measured by need for inotropic agents, was also correlated with interleukin 6 concentration: amount of interleukin 6 in serum on admission was high in patients with severe shock needing high-dose inotropes (figure $6 \mathrm{~B}$ ).

\section{Discussion}

We have shown that interleukin 6 has an important role in myocardial depressant activity of meningococcal serum. The time course of release of interleukin 6 and its molecular weight accorded with the known properties of the myocardial depressant factor or factors. ${ }^{8}$ Recombinant interleukin 6 mimicked the myocardial depressant effect of meningococcal serum on rat cardiac myocytes, and removal of this cytokine from patients' serum or meningococcal-stimulated peripheral blood mononuclear cell supernatant abolished activity. The close correlation of serum concentrations of interleukin 6 on admission with severity of cardiovascular failure in meningococcal disease and of clinical disease severity lends support to the clinical relevance of our findings.

Interleukin 6 is a PLEIOTROPIC CYTOKINE that has been characterised as a biomarker of early inflammatory responses in sepsis. Findings of studies in a few patients with meningococcal disease have established a relation between interleukin 6 and disease severity, ${ }^{17-20}$ which we have confirmed in our cohort of 140 patients. Concentrations of interleukin 6 remain raised for some 24-48 h after disease presentation, which could account for the persistent cardiac dysfunction seen during the early days following the onset of septicaemia.

Despite the well-documented release of interleukin 6 in sepsis, it has not generally been regarded as a central mediator in the pathophysiology of septic shock, and unlike $\mathrm{TNF} \alpha$ and interleukin $1 \beta$, has not attracted attention as a therapeutic target for trials of antiinflammatory agents in sepsis. Published work shows that $\mathrm{TNF}_{\alpha}$ and interleukin $1 \beta$ are implicated in myocardial dysfunction of sepsis. ${ }^{3}$ However, our results in meningococcal disease do not preclude a role for $\mathrm{TNF} \alpha$ and interleukin $1 \beta$ in myocardial depression of septic shock. We did not note any negative inotropic effect of these cytokines. TNF $\alpha$ might have some synergistic activity on prolonged exposure.

Gene microarray analysis of changes in RNA expression on exposure of blood to meningococci adds a new dimension to our understanding of the inflammatory process. In addition to known inflammatory proteins, such as $\mathrm{TNF} \alpha$ and other cytokines, hundreds of other genes are upregulated after exposure of blood to meningococci, many of whose functions are not known. However, although this technology has provided an insight into the complexity of the process, our findings show that it can also be used to elucidate mechanisms if information from the microarray can be linked to a carefully defined biological question and combined with data from conventional biochemical analysis. By relating data from the gene expression profile of meningococcus-activated whole blood to specific physical characteristics of the myocardial depressant factor or factors, we were able to rapidly identify candidate proteins to screen for myocardial depressant activity in our established bioassay.

Although we used only two donors for the gene array strategy, the pattern of inflammatory response induced by meningococci on exposure to whole blood has now been extensively documented. ${ }^{21-23}$ We have previously shown that addition of $10^{8}$ meningococci to whole blood induces a highly consistent response, with release into the plasma of cytokines such as $\mathrm{TNF} \alpha$ and neutrophil products including elastase, and alteration in expression of adhesion molecules, all happening within $3 \mathrm{~h}$ of exposure. ${ }^{21-23}$ Release of myocardial depressant activity into the supernatant of meningococcus-activated whole blood is also at a maximum at about $3 \mathrm{~h} .{ }^{8}$ The pattern of gene expression noted with the microarray accords with previous data on the inflammatory response studied at a protein level.

Interleukin 6 has been shown to depress papillary muscle contraction, ${ }^{24}$ and is negatively inotropic in cultures of isolated chick and guineapig ventricular myocytes. ${ }^{25,26}$ Our finding that the myocardial depressant activity of serum from patients with meningococcaemia is completely removed by affinity-adsorption of interleukin 6 , and that concentrations of this cytokine correlate with cardiovascular morbidity, lend support to the view that interleukin 6 is the principal mediator of myocardial depression in meningococcal sepsis.

The mechanisms by which interleukin 6 exerts negative inotropic activity are not well documented. Our previous work suggested that the nitric oxide-cyclic GMP pathway was not involved in the negative inotropic activity of meningococcal serum. ${ }^{8}$ Furthermore, interleukin 6 can bind directly to cells expressing the cellbound or soluble interleukin 6 receptor, which interacts with the ubiquitous gp130 receptor. Changes in expression of cellular or soluble receptors may affect activity of this cytokine in sepsis.

Interleukin 6 is upregulated in many infectious and inflammatory states, including cardiac surgery, cardiogenic shock, and coronary bypass, ${ }^{27,28}$ and in gramnegative and gram-positive sepsis. If this cytokine is indeed a major mediator of myocardial depression, as our findings indicate, then treatment to block or neutralise the myocardial depressant effects of

\section{RELEVANCE OF THIS PAPER TO PRACTICE}

BACKGROUND

Septic shock is a complex catastrophic illness, which can progress rapidly to death. Dissecting out all the parts of this illness is difficult, especially because large samples are often not available from very sick patients.

One distinct component of this illness in meningococcal sepsis is myocardial dysfunction, which this paper focused on. By use of an in-vitro model of septic shock it was possible to select from large numbers of genes six that were potentially implicated in the myocardial dysfunction. Then, using samples from children with meningococcal sepsis it was possible to show that removal of one of these proteins, interleukin 6 , abrogated ability of the samples to cause myocardial depression-again in vitro. Finally, interleukin 6 was associated with clinical outcome.

IMPLICATIONS

This paper links together gene expression analysis, physiology, and prognosis to identify interleukin 6 as a plausible cause of myocardial dysfunction in septic shock, which warrants further investigation as a therapeutic target. 
interleukin 6 could be a promising therapeutic direction, not only in septic shock but also in other inflammatory conditions associated with myocardial dysfunction.

\section{Contributors}

N Pathan developed the research strategy, planned, undertook, and analysed all experimental work, wrote the manuscript, and coordinated input of all other authors. C A Hemingway, A A Alizadeh, and J C Boldrick developed and undertook the microarray strategy and analysed microarray findings. A Whitney assisted with the microarray procedure. A C Stephens, E E Oragui, C McCabe, and P O'Gara developed the interleukin 6 analysis. A C Stephens planned, undertook, and analysed cytokine immunoadsorption. E E Oragui undertook and analysed cytokine ELISAs. C McCabe and P O'Gara undertook and analysed effects of recombinant cytokines on myocyte contraction. P O'Gara also prepared cardiac myocytes. S B Welch developed the whole-blood stimulation section, and planned, undertook, and analysed effects of meningococcal stimulation of whole blood. $S$ Nadel assisted in the clinical section of the paper, selected clinical criteria for analysis of patients' cytokine amounts, and analysed the association between clinical disease severity and serum cytokine levels. D A Relman directed development of the microarray strategy and planned and analysed the microarray. S E Harding directed development of the myocyte contraction assay and planned and analysed all experimental data relating to the myocyte contraction assay. M Levin developed the research strategy, planned, analysed, and supervised all aspects of the experimental work, wrote the manuscript, and coordinated input of all other authors. All authors helped to write the paper and approved the final version. C A Hemingway and A A Alizadeh contributed equally to this work.

\section{Conflict of interest statement}

None declared.

\section{Acknowledgements}

We thank H Sun, P Molenaar, and H Gong for assistance with myocyte contraction analysis; S Kim from Xoma, Berkeley, CA, for analysis of patients' interleukin 6 concentrations and morbidity; S Popper who assisted with microarray analysis; and L M Stuart and P Langford who commented on the manuscript. Funded in part by a programme grant from the Meningitis Research Foundation (ML), a junior fellowship from the British Heart Foundation (NP) and a Wellcome Trust, BurroughsWellcome infectious disease initiative award (ML).

\section{References}

1 Thalinger AR, Lefer AM. Cardiac actions of a myocardial depressant factor isolated from shock plasma. Proc Soc Exp Biol Med 1971; 136: 354-58.

2 Parrillo JE, Burch C, Shelhamer JH, Parker MM, Natanson C, Schuette W. A circulating myocardial depressant substance in humans with septic shock: septic shock patients with a reduced ejection fraction have a circulating factor that depresses in vitro myocardial cell performance. $\mathcal{F}$ Clin Invest 1985; 76: 1539-53.

3 Kumar A, Thota V, Dee L, Olson J, Uretz E, Parrillo JE. Tumor necrosis factor alpha and interleukin 1beta are responsible for in vitro myocardial cell depression induced by human septic shock serum. f Exp Med 1996; 183: 949-58.

4 Sagher U, Rosen H, Sarel O, Becker Y. Studies on a pancreatic cardiodepressant factor. Circ Shock 1986; 19: 319-26.

5 Bennasayag C, Christeff N, Auclair MC, et al. Early released lipid soluble cardiodepressant factor and elevated oestrogenic substances in human septic shock. Eur f Clin Invest 1984; 14: 288-94.

6 Balligand JL, Ungureanu D, Kelly RA, et al. Abnormal contractile function due to induction of nitric oxide synthesis in rat cardiac myocytes follows exposure to activated macrophage-conditioned medium. F Clin Invest 1993; 91: 2314-19.
7 Mercier JC, Beaufils F, Hartmann JF, Azema D. Hemodynamic patterns of meningococcal shock in children. Crit Care Med 1988; 16: 27-33.

8 Pathan N, Sandiford C, Harding SE, Levin M. Characterization of a myocardial depressant factor in meningococcal septicemia. Crit Care Med 2002; 30: 2191-98.

9 Pollack MM, Patel KM, Ruttimann UE. PRISM III: an updated Pediatric Risk of Mortality score. Crit Care Med 1996; 24: 743-52.

10 Wang E, Miller LD, Ohnmacht GA, Liu ET, Marincola FM. High-fidelity mRNA amplification for gene profiling. Nat Biotechnol 2000; 18: 457-59.

11 Alizadeh AA, Eisen MB, Davis RE, et al. Distinct types of diffuse large B-cell lymphoma identified by gene expression profiling. Nature 2000; 403: 503-11.

12 Liu CL. Data processing of time course data. http://genetics.stanford. edu/ cliu/proc.html (accessed Nov 3, 2003).

13 Eisen M. Microarrays.org: software. http://www.microarrays.org/ software.html (accessed Oct 1, 2003).

14 Brazma A, Hingamp P, Quackenbush J, et al. Minimum information about a microarray experiment (MIAME)-toward standards for microarray data. Nat Genet 2001; 29: 365-71.

15 Stanford Microarray Database. http://genomewww5.stanford.edu/MicroArray/SMD/ (accessed Oct 1, 2003).

16 Levin M, Quint PA, Goldstein B, et al. Recombinant bactericidal/permeability-increasing protein (rBPI21) as adjunctive treatment for children with severe meningococcal sepsis: a randomised trial. Lancet 2000; 356: 961-67.

17 Gardlund B, Sjolin J, Nilsson A, Roll M, Wickerts CJ, Wretlind B. Plasma levels of cytokines in primary septic shock in humans: correlation with disease severity. F Infect Dis 1995; 172: 296-301.

18 Hazelzet JA, van der Voort E, Lindemans J, ter Heerdt PG, Neijens HJ. Relation between cytokines and routine laboratory data in children with septic shock and purpura. Intensive Care Med 1994; 20: 371-74.

19 Hazelzet JA, Risseeuw-Appel IM, Kornelisse RF, et al. Age-related differences in outcome and severity of DIC in children with septic shock and purpura. Thromb Haemost 1996; 76: 932-38.

20 van Deuren $M$, van der Ven-Jongekrijg J, Bartelink AK, van Dalen R, Sauerwein RW, van der Meer JW. Correlation between proinflammatory cytokines and antiinflammatory mediators and the severity of disease in meningococcal infections. F Infect Dis 1995; 172: 433-39.

21 Klein NJ, Ison CA, Peakman M, et al. The influence of capsulation and lipooligosaccharide structure on neutrophil adhesion molecule expression and endothelial injury by Neisseria meningitidis. F Infect Dis 1996; 173: 172-79.

22 Chan B, Kalabalikis P, Klein N, Heyderman R, Levin M. Assessment of the effect of candidate anti-inflammatory treatments on the interaction between meningococci and inflammatory cells in vitro in a whole blood model. Biotherapy 1996; 9: 221-28.

23 Heyderman RS, Ison CA, Peakman M, Levin M, Klein NJ. Neutrophil response to Neisseria meningitidis: inhibition of adhesion molecule expression and phagocytosis by recombinant bactericidal/permeability-increasing protein (rBPI21). F Infect Dis 1999; 179: 1288-92.

24 Finkel MS, Oddis CV, Jacob TD, Watkins SC, Hattler BG, Simmons RL. Negative inotropic effects of cytokines on the heart mediated by nitric oxide. Science 1992; 257: 387-89.

25 Kinugawa K, Takahashi T, Kohmoto O, et al. Nitric oxide-mediated effects of interleukin- 6 on $[\mathrm{Ca} 2+] \mathrm{i}$ and cell contraction in cultured chick ventricular myocytes. Circ Res 1994; 75: 285-95.

26 Sugishita K, Kinugawa K, Shimizu T, et al. Cellular basis for the acute inhibitory effects of IL-6 and TNF-alpha on excitationcontraction coupling. f Mol Cell Cardiol 1999; 31: 1457-67.

27 Hovels-Gurich HH, Vazquez-Jimenez JF, Silvestri A, et al. Production of proinflammatory cytokines and myocardial dysfunction after arterial switch operation in neonates with transposition of the great arteries. F Thorac Cardiovasc Surg 2002; 124: 811-20.

28 Geppert A, Steiner A, Zorn G, et al. Multiple organ failure in patients with cardiogenic shock is associated with high plasma levels of interleukin-6. Crit Care Med 2002; 30: 1987-94. 